\title{
Genetic architecture study of rheumatoid arthritis and juvenile idiopathic arthritis
}

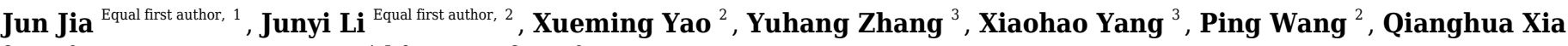 \\ Corresp., 2 , Hakon Hakonarson ${ }^{4,5,6}$, Jin Li ${ }^{\text {Corresp. } 2}$ \\ 1 Department of Surgery of Foot and Ankle, Tianjin Hospital, Tianjin, China \\ Department of Cell Biology, 2011 Collabo
Tianjin Medical University, Tianjin, China \\ 3 Tianjin University of Traditional Chinese Medicine, Tianjin, China \\ ${ }^{4}$ Center for Applied Genomics, Children's Hospital of Philadelphia, Philadelphia, Pennsylvania, United States \\ 5 Division of Human Genetics, Children's Hospital of Philadelphia, Philadelphia, Pennsylvania, United States \\ 6 Department of Pediatrics, Perelman School of Medicine, University of Pennsylvania, Philadelphia, Pennsylvania, United States \\ Corresponding Authors: Qianghua Xia, Jin Li \\ Email address: qhxia@tmu.edu.cn, jli01@tmu.edu.cn
}

Background. Rheumatoid arthritis and juvenile idiopathic arthritis are two types of autoimmune diseases with inflammation at the joints, occurring to adults and children respectively. There are phenotypic overlaps between these two types of diseases, despite the age difference in patient groups.

Methods. To systematically compare the genetic architecture of them, we conducted analyses at the gene and pathway levels and constructed protein-protein-interaction network based on summary statistics of genome-wide association studies of these two diseases. We examined their difference and similarity at each level.

Results. We observed extensive overlap in significant SNPs and genes at the human leukocyte antigen region. In addition, several SNPs in other regions of the human genome are also significantly associated with both diseases. We found significantly associated genes are enriched in 32 pathways shared by both diseases. After genes in human leukocyte antigen region being removed, significant enrichment is present for pathways like interleukin-27 pathway and NO2-dependent interleukin-12 pathway in natural killer cells.

Discussion. The identification of commonly associated genes and pathways may help in finding population at risk for both diseases, as well as shed light on repositioning and designing drugs for both diseases. 
1 Genetic Architecture Study of Rheumatoid Arthritis and Juvenile

Idiopathic Arthritis

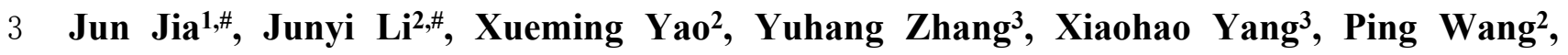

4 Qianghua Xia ${ }^{2, *}$, Hakon Hakonarson ${ }^{4,5,6}, \mathbf{J i n} \mathbf{L i}^{2, * *}$

$5 \quad{ }^{1}$ Department of Surgery of Foot and Ankle, Tianjin Hospital, Tianjin, China

62 Department of Cell Biology, 2011 Collaborative Innovation Center of Tianjin for Medical

7 Epigenetics, Tianjin Key Laboratory of Medical Epigenetics, Tianjin Medical University,

8 Tianjin, China

$9 \quad{ }^{3}$ Tianjin University of Traditional Chinese Medicine, Tianjin, China

$10{ }^{4}$ Center for Applied Genomics, Children's Hospital of Philadelphia, Philadelphia, PA, United

11 States

$12{ }^{5}$ Division of Human Genetics, Children's Hospital of Philadelphia, Philadelphia, PA, United

13 States

$14{ }^{6}$ Department of Pediatrics, Perelman School of Medicine, University of Pennsylvania,

15 Philadelphia, PA, United States

16 \#Jun Jia and Junyi Li contributed equally to this work.

*Corresponding authors:

19 Qianghua Xia, Ph.D.

2022 Meteorological Station Road, HePing District, Tianjin, China

21 qianghua@gmail.com

22 Jin Li, Ph.D.

2322 Meteorological Station Road, HePing District, Tianjin, China

24 jli01@tmu.edu.cn 


\section{Abstract}

27 Background. Rheumatoid arthritis and juvenile idiopathic arthritis are two types of autoimmune diseases with inflammation at the joints, occurring to adults and children respectively. There are phenotypic overlaps between these two types of diseases, despite the age difference in patient groups.

Methods. To systematically compare the genetic architecture of them, we conducted analyses at the gene and pathway levels and constructed protein-protein-interaction network based on summary statistics of genome-wide association studies of these two diseases. We examined their difference and similarity at each level.

Results. We observed extensive overlap in significant SNPs and genes at the human leukocyte significantly associated with both diseases. We found significantly associated genes are enriched in 32 pathways shared by both diseases. After genes in human leukocyte antigen region being removed, significant enrichment is present for pathways like interleukin-27 pathway and NO2dependent interleukin-12 pathway in natural killer cells.

Discussion. The identification of commonly associated genes and pathways may help in finding population at risk for both diseases, as well as shed light on repositioning and designing drugs for both diseases.

Keywords: juvenile idiopathic arthritis, rheumatoid arthritis, genome-wide association studies, genetic architecture comparison, pathway enrichment 


\section{Introduction}

Rheumatoid arthritis (RA) is a symmetric polyarticular arthritis that primarily affects the small diarthrodial joints of the hands and feet, while Juvenile idiopathic arthritis (JIA) is caused by unknown etiology and persists at least 6 weeks in children under the age of 16, which does not contain other known conditions (Firestein 2003; Prakken et al. 2011). The prevalence rate of RA varies from 0.41 to $0.54 \%$ from 2004 to 2014 based on US administrative health insurance claims databases (Hunter et al. 2017), which is observably greater than the prevalence rate of JIA ranging from 0.0038 to $0.40 \%$ according to a systematic literature review including 29 articles (Thierry et al. 2014).

Phenotypically, RA and JIA are similar in some aspects. They show some common symptoms and physical signs such as joint pain and swelling, limited joint mobility and deformity, morning stiffness, elevated rheumatoid factor, fever, etc. Some of the subtypes of JIA, such as polyarticular JIA, are particularly similar to RA. However, with distinct clinical and pathological features of these two diseases being noted, they have been defined as separate diseases by International League of Associations for Rheumatology (Petty et al. 2004). In particular, JIA is heterogeneous with variable clinical presentation and outcome. It has been classified into seven subtypes, including oligoarticular JIA (persistent/ extended), polyarticular JIA with negative rheumatoid factor (RF), polyarticular JIA with positive RF, psoriatic JIA, enthesitis related arthritis, systemic JIA and undifferentiated JIA (Nigrovic et al. 2018). RA is more homogeneous but with a poorer outcome.

It has long been recognized that both RA and JIA are related to autoimmune and inflammatory disorders (Ravelli \& Martini 2007; Scott et al. 2010). Population based heritability estimates for RA and JIA are both 60\% approximately (Prahalad 2006). Single nucleotide polymorphism (SNP) based heritability for RA has been reported to be around $50 \%$ (Speed \& Balding 2014; Speed et al. 2012), slightly lower than that of JIA estimated to be $73 \%$ (Li et al. 2015b). Certain alleles in the HLA region are strong genetic predisposition factors for RA and JIA. It has been reported that for both RA and JIA, the odds ratio of HLA region is about 2.8, while that of most non-HLA loci is only 1.1 to 1.4. (Nigrovic et al. 2018; O. Hersh \& Prahalad 2015; Viatte et al. 2013) The genetic predisposition of JIA is attributable to HLA class II molecules (HLA-DRB1, HLA-DPB1), HLA class I molecules and non-HLA genes. The clinical presentation of RF-positive JIA resembles that of RA, and they share the HLA-DRB1 epitope. (De Silvestri et al. 2017; Hinks et al. 2018) The HLA-DRB1*04 confers a protective role in JIA before the age of 6, while it renders an increased risk of RA. (Nigrovic et al. 2018) The immunopathogenesis of RA has become clear in recent years, but the pathogenesis of JIA remains unknown (Firestein \& McInnes 2017; Mellins et al. 2011).

With the rapid development of genomic technology, a large number of genetic variants associated with RA or JIA have been identified. To date, genome-wide association studies (GWASs) have identified a large number of variants associated with RA and JIA respectively. A total of 789 RA-associated variants from 52 studies and 129 JIA-associated variants from 11 studies have been reported in GWAS Catalog (association testing P-value $<1 \times 10^{-5}$ ) (Buniello et al. 2019), including 101 loci associated with RA and around 30 loci associated with JIA at genome-wide significant level. We aimed to compare the genetic architecture of RA and JIA at multiple levels systematically. 
91

92

93

94

95

96

97

98

99

100

101

102

103

104

105

106

107

108

109

110

111

112

113

114

115

116

117

118

119

120

121

122

123

124

125

126

127

128

129

In this study, we conducted gene, pathway and network analyses of RA and JIA using robust and computational efficient methods based on their summary GWAS statistics. We compared genetic difference and similarity between RA and JIA, identified their shared genetic signature. Significant overlap in genes and pathways were observed between these two diseases.

\section{Materials and Methods \\ Data collection}

RA genetic loci information came from GWAS summary statistics of a trans-ethnic study (Okada et al. 2014) including a total of 29,880 RA cases and 73,758 controls of European and Asian ancestries. Summary statistics was downloaded from GWAS catalog ${ }^{1}$ (Buniello et al. 2019). All RA patients met the RA diagnostic criteria established by the American College of Rheumatology in 1987 (Arnett et al. 1988), or were confirmed by a professional rheumatologist (Okada et al. 2014).

JIA genetic loci information came from two resources. First, summary statistics of our previous GWAS on JIA (Finkel et al. 2016) was included in the current study. Our JIA GWAS is composed of discovery and replication cohorts with 1166 JIA cases and 9500 unrelated controls of European ancestry totally. Summary statistics of meta-analysis on the discovery and replication cohorts were used in our current study. Second, JIA variants revealed in published GWASs (Behrens et al. 2008; Cobb et al. 2014; Finkel et al. 2016; Hinks et al. 2009; Hinks et al. 2013; Li et al. 2015a; Ombrello et al. 2017; Thompson et al. 2012) were extracted from GWAS catalog (Buniello et al. 2019).

\section{Gene-based association analysis}

A gene-based association analysis for RA and JIA was performed using fastBAT method (Bakshi et al. 2016) implemented in GCTA v1.91.7 (Yang et al. 2011) respectively, based on GWAS summary statistics of RA or JIA and linkage disequilibrium (LD) from EUR population in $1000 \mathrm{G}$ project (The Genomes Project et al. 2015). Each gene region was defined as its transcript region and $50 \mathrm{~kb}$ upstream/downstream, and the threshold for LD pruning was set to $\mathrm{r}^{2}$ value $>0.9$, following the default setting of fastBAT. The gene list of human genome used by fastBAT method contains 24765 annotated genes (Bakshi et al. 2016), thus the genome-wide significant threshold for gene based tests was set at $0.05 / 24765=2 \times 10^{-6}$. JIA SNPs in GWAS catalog was also mapped to genes according to its report (Buniello et al. 2019).

\section{Protein-protein interaction network and pathway enrichment analyses}

Competitive pathway enrichment analysis and protein-protein interaction (PPI) network visualization analysis were both performed using GWAS summary-level data by GSA-SNP2 2 . (Yoon et al. 2018) The LD information in the European population from the 1000 Genomes Project (The Genomes Project et al. 2015) was used to reduce false positives by combining highly correlated adjoining genes. Each gene region was defined as its transcript region and $20 \mathrm{~kb}$ upstream/downstream, as the default setting of GSA-SNP2. Gene-set database used for pathway construction were $C 2$ (curated gene sets) $C P$ (canonical pathways)v5.2, which is a collection of

\footnotetext{
1 https://www. ebi. ac. uk/gwas/

2 https://sites. google. com/view/gsasnp2
} 
130 online pathway databases such as BioCarta ${ }^{3}$ (Nishimura 2001), KEGG ${ }^{4}$ (Kanehisa et al. 2017; 131 Kanehisa \& Goto 2000; Kanehisa et al. 2019), Reactome ${ }^{5}$ (Fabregat et al. 2018) and DIP 132 (Schaefer et al. 2009) by Molecular Signatures Database (MSigDB) ${ }^{6}$ (Liberzon et al. 2015; 133 Liberzon et al. 2011; Subramanian et al. 2005). The network data resource was the STRING

134 database (https://string-db.org/) (Szklarczyk et al. 2015) Multiple-testing adjustment was performed and Q-value $<0.05$ was set as the significance threshold. Global visual networks were constructed at a threshold of gene-score $<0.005$ and Q-value $<0.05$.

\section{Results}

\section{SNP-level comparison}

A total of 26285 SNPs (Supplementary Table 1) in RA study and 105 SNPs (Supplementary Table 2, Supplementary Table 3) in JIA study reached genome-wide significance threshold P-value $<5 \times 10^{-8}$, and these two diseases shared 47 significant SNPs. Among these SNPs, 37 were located in the human leukocyte antigen (HLA) region on chromosome 6. The rest 10 SNPs were located in or close to 9 genes (Table 1). Interestingly, 8 SNPs located in the HLA region showed opposite direction of effects, which means risk allele of JIA could be protective allele for RA and vice versa.

\section{Gene-based comparison}

To increase statistical power and to consider the combined effects of SNPs in genes, we conducted gene-disease association analyses, based on SNP summary statistics and taking into account of LD information between SNPs. Several methods have been developed for computing gene level associations based on SNP summary statistics, such as the commonly used PLINK (Purcell et al. 2007) set-baesd test and software VEGAS (Versatile Gene-based Association Study)(Liu et al. 2010), which are permutation and simulation-based approaches respectively. Both methods rely on resampling which is computationally intensive. Here, we adopted the fastBAT method which was a robust set-based association test computing the P-value of a gene with a number of SNPs from an approximated distribution. (Bakshi et al. 2016) 431 genes located at 50 loci reached genome-wide significance in the RA dataset, including 17 known loci (Acosta-Herrera et al. 2019; Buniello et al. 2019; Eyre et al. 2012; Plenge et al. 2005; Raychaudhuri et al. 2009; Zhu et al. 2016) and 33 novel which should be examined in future replication studies (Supplementary Table 4).

However only genes in the HLA region showed genome-wide significant association with JIA, which was likely due to the limited power of our previous GWAS (Supplementary Table 5). A total of 75 significant genes in the HLA region were shared by JIA and RA (Supplementary Table 6). Then we checked whether additional significant genes in RA contained genome wide significant SNPs in JIA reported in GWAS catalog. Not surprisingly, one RA significant gene in the HLA region and 8 genes outside the HLA region containing genome-wide significant SNPs for JIA (Table 2) were observed. Because the fastBAT method conducted LD-pruning before combining SNP statistics, the top SNP showed in Table 2 may not

${ }^{3}$ http://www. biocarta. com/

4 https://www. genome.jp/kegg/

${ }^{5}$ https://reactome. org/

${ }^{6}$ http://software. broadinstitute. org/gsea/msigdb 
be the one with the best P-value in original GWAS.

\section{Pathway-level comparison}

GWAS pathway analysis consider either competitive null hypothesis or self-contained null hypothesis. Many methods for GWAS pathway analysis have been developed, but they are still subjected to the issues of low power and being influenced by some free parameters. The recently developed GSA-SNP2 package (Yoon et al. 2018) used the random set model to compute pathway enrichment with decent type I error control by integrating the gene scores adjusted by the number of SNPs mapped to each gene and removing high inter-gene correlated adjacent genes in each pathway. It does not require any key free parameters concurrently. We applied this method to our analyses. RA or JIA associated genes were enriched in numerous canonical pathways at a threshold of Q-value $<0.05$. A total of 32 enriched pathways were shared by RA and JIA, mostly were immune-related pathways, such as allograft rejection, type 1 diabetes mellitus, graft versus host disease, antigen processing and presentation, autoimmune thyroid disease, asthma, etc. (Supplementary Table 7) Most of these significant pathways were driven by genes in the HLA region. In order to explore the role of loci outside the HLA region for these two diseases, we performed pathway enrichment analysis again after removing loci in the HLA region based on their genomic coordinates. The HLA region was defined as chr6:28,477,79733,448,354 (GRCh37/hg19). Pathways such as Interleukin(IL)-27 pathway and NO2-dependent IL-12 pathway in natural killer (NK) cells were significantly enriched even after the HLA region loci were removed (Table 3). Global networks were visualized at a threshold of gene-score < 0.005 (Figure 1\&2). We observed the common hub role of several genes such as TYK2. The networks before removing the HLA region were shown in Supplementary Figure 1 and 2.

\section{Discussion}

Despite the phenotypic similarity between JIA and RA, systematic comparison of genetic similarity and distinction between these two types of diseases are lacking. Large scale GWASes of RA and JIA respectively render us ability to conduct such comparison, identifying potential common mechanism in disease pathogenesis which may help repositioning and designing disease treatment strategies.

To systematically compare the genetic architecture of the two diseases, we performed genelevel, pathway-level analyses and conducted comparison at each level. Not only did we observe a large amount of overlaps in the HLA region as expected, but we also observed several SNPs and genes which significantly associated with both diseases in the regions other than the HLA region. Among them, the risk alleles of several SNPs were different between the two diseases, which means that a certain allele may play a risk role in one disease but a protective role in the other. These SNPs might be related to the differences in pathogenesis and phenotype between JIA and RA. As we did not perform genome-wide imputation analysis due to unavailability of individuallevel data, the number of genome-wide significant SNPs shared by these two diseases was actually underestimated.

Due to the limited sample size of our JIA data, we could not perform analysis for each subtype of JIA with enough statistical power. However, the heterogenous nature of JIA and the genetic basis of its subtypes are worth noting. Some HLA alleles show different directions of effects on different subtypes of JIA and RA. For instance, HLA-DRB1*8, HLA-DRB1*11 and 
212 HLA-DRB1*13 are risk alleles of seronegative JIA, but do not exhibit association with 213 seropositive polyarticular JIA and seronegative RA, and these HLA alleles render protective 214 effect for seropositive RA. In particular, DRB1*11 is also a risk allele of systemic JIA, while the 215 other two alleles are not associated with this JIA subtype.(Nigrovic et al. 2018) As for alleles 216 outside the HLA region, certain SNPs in genes PTPN22 and STAT1/STAT4 do not show 217 association with systemic JIA, but confer risk for most other subtypes of JIA and RA.(Nigrovic 218 et al. 2018) In a recent study, Hinks et al demonstrated that RF-positive polyarticular JIA is more 219 similar to adult RA compared to other JIA subtypes in terms of genetic profile examined on 220 Immunochip. (Hinks et al. 2018; Onuora 2018) Further analysis of the genetic nature of different may lead to more effective treatment, better prognosis.

We observed significant enrichment of NO2-dependent IL12 pathway and IL27 pathway for both RA and JIA. Macrophages release IL-12 which plays an important role in activation of NK cells and induces cytotoxicity with nitric oxide (NO).(Liu et al. 2005) NK cells are regarded as a bridge between innate and adaptive immunity, serving as a key regulator in the pathogenesis and development of autoimmune diseases.(Gianchecchi et al. 2018) It have been reported that high percentages of NK cells and their activity were found in the synovial fluid of active RA patients at advanced stage(Yamin et al. 2019), and dysfunction of NK cell was also observed in patients with systemic-onset JIA and its complication.(Grom et al. 2003) NO2-dependent IL12 pathway plays a unique role in the activation of NK cells by macrophage. The enrichment of this pathway in our analyses implies the potential role of abnormal IL-12-mediated activation of NK cell in the pathogenesis of RA and JIA. IL-12 has long been considered as a therapeutic target of arthritis and other autoimmune and inflammatory disorders (Hasko \& Szabo 1999; Siebert et al. 2015). As a member of the IL-12 family, IL-27 induces T cell differentiation and causes immunosuppressive effects by inhibiting the development of Th17 cells.(Yoshida \& Miyazaki 2008) Previous studies have suggested that IL-27 is another key modulator of autoimmunity and elevation of IL-27 signaling may be inhibitory to some autoimmune diseases, such as multiple sclerosis or uveitis.(Amadi-Obi et al. 2007) Our results suggest that such therapeutic approach may be also applied to the management of RA and JIA.

\section{Conclusion}

Our study identifies genetic similarity and differences between RA and JIA at multiple levels. We observed a number of genes being associated with both diseases especially in the HLA region, and distinct genetic loci were found as well. Such systematic comparison and further functional characterization of these genetic loci, and signaling pathways may lead to the identification of common drug targets for both diseases, drug repositioning and may also contribute to the precision treatment of each disease.

\section{Acknowledgments}

This study was supported by National Natural Science Foundation of China (81771769), Tianjin Natural Science Foundation (18JCYBJC42700), Startup Funding from Tianjin Medical University. 


\section{Author Contributions}

256 Q.X., H.H. and J.L. designed the study; J.J., J.Y.L., X.M.Y. and P.W. performed the data 257 analysis; Y.Z. and X.H.Y. were involved in results interpretation; J.Y.L., J.J., Q.X. and J.L. 258 wrote the manuscript. All authors have reviewed and provided revisions and have agreed on the 259 submitted version of the paper.

260

\section{Conflicts of Interests}

262 All the authors declare no conflicts of interest. 


\section{References}

Acosta-Herrera M, Kerick M, Gonzalez-Serna D, Wijmenga C, Franke A, Gregersen PK, Padyukov L, Worthington J, Vyse TJ, Alarcon-Riquelme ME, Mayes MD, and Martin J. 2019. Genome-wide meta-analysis reveals shared new loci in systemic seropositive rheumatic diseases. Ann Rheum Dis 78:311-319. 10.1136/annrheumdis-2018-214127

Amadi-Obi A, Yu CR, Liu X, Mahdi RM, Clarke GL, Nussenblatt RB, Gery I, Lee YS, and Egwuagu CE. 2007. TH17 cells contribute to uveitis and scleritis and are expanded by IL-2 and inhibited by IL27/STAT1. Nat Med 13:711-718. 10.1038/nm1585

Arnett FC, Edworthy SM, Bloch DA, McShane DJ, Fries JF, Cooper NS, Healey LA, Kaplan SR, Liang MH, Luthra HS, Medsger TA, Mitchell DM, Neustadt DH, Pinals RS, Schaller JG, Sharp JT, Wilder RL, and Hunder GG. 1988. The American Rheumatism Association 1987 revised criteria for the classification of rheumatoid arthritis. Arthritis Rheum 31:315-324.

Bakshi A, Zhu Z, Vinkhuyzen AAE, Hill WD, McRae AF, Visscher PM, and Yang J. 2016. Fast set-based association analysis using summary data from GWAS identifies novel gene loci for human complex traits. Scientific Reports 6:32894. 10.1038/srep32894

https://www.nature.com/articles/srep32894\#supplementary-information

Behrens EM, Finkel TH, Bradfield JP, Kim CE, Linton L, Casalunovo T, Frackelton EC, Santa E, Otieno FG, Glessner JT, Chiavacci RM, Grant SF, and Hakonarson H. 2008. Association of the TRAF1-C5 locus on chromosome 9 with juvenile idiopathic arthritis. Arthritis Rheum 58:2206-2207. 10.1002/art.23603

Buniello A, Jacqueline A, Cerezo M, Harris LW, Hayhurst J, Malangone C, McMahon A, Morales J, Mountjoy E, Sollis E, Suveges D, Vrousgou O, Whetzel PL, Amode R, Guillen JA, Riat HS, Trevanion SJ, Hall P, Junkins H, Flicek P, Burdett T, Hindorff LA, Cunningham F, and Parkinson H. 2019. The NHGRI-EBI GWAS Catalog of published genome-wide association studies, targeted arrays and summary statistics 2019. Nucleic Acids Research 47:D1005-D1012. 10.1093/nar/gky1120

Cobb J, Cule E, Moncrieffe H, Hinks A, Ursu S, Patrick F, Kassoumeri L, Flynn E, Bulatovic M, Wulffraat N, van Zelst B, de Jonge R, Bohm M, Dolezalova P, Hirani S, Newman S, Whitworth P, Southwood TR, De lorio M, Wedderburn LR, and Thomson W. 2014. Genome-wide data reveal novel genes for methotrexate response in a large cohort of juvenile idiopathic arthritis cases. Pharmacogenomics J 14:356-364. 10.1038/tpj.2014.3

De Silvestri A, Capittini C, Poddighe D, Marseglia GL, Mascaretti L, Bevilacqua E, Scotti V, Rebuffi C, Pasi A, Martinetti M, and Tinelli C. 2017. HLA-DRB1 alleles and juvenile idiopathic arthritis: Diagnostic clues emerging from a meta-analysis. Autoimmun Rev 16:1230-1236. https://doi.org/10.1016/j.autrev.2017.10.007

Eyre S, Bowes J, Diogo D, Lee A, Barton A, Martin P, Zhernakova A, Stahl E, Viatte S, McAllister K, Amos $\mathrm{Cl}$, Padyukov L, Toes RE, Huizinga TW, Wijmenga C, Trynka G, Franke L, Westra HJ, Alfredsson L, Hu X, Sandor C, de Bakker PI, Davila S, Khor CC, Heng KK, Andrews R, Edkins S, Hunt SE, Langford C, Symmons D, Concannon P, Onengut-Gumuscu S, Rich SS, Deloukas P, GonzalezGay MA, Rodriguez-Rodriguez L, Arlsetig L, Martin J, Rantapaa-Dahlqvist S, Plenge RM, Raychaudhuri S, Klareskog L, Gregersen PK, and Worthington J. 2012. High-density genetic mapping identifies new susceptibility loci for rheumatoid arthritis. Nat Genet 44:1336-1340. 10.1038/ng.2462

Fabregat A, Jupe S, Matthews L, Sidiropoulos K, Gillespie M, Garapati P, Haw R, Jassal B, Korninger F, May B, Milacic M, Roca CD, Rothfels K, Sevilla C, Shamovsky V, Shorser S, Varusai T, Viteri G, Weiser J, Wu G, Stein L, Hermjakob H, and D'Eustachio P. 2018. The Reactome Pathway Knowledgebase. Nucleic Acids Res 46:D649-d655. 10.1093/nar/gkx1132

Finkel TH, Li J, Wei Z, Wang W, Zhang H, Behrens EM, Reuschel EL, Limou S, Wise C, Punaro M, Becker ML, Munro JE, Flato B, Forre O, Thompson SD, Langefeld CD, Glass DN, Glessner JT, Kim CE, Frackelton E, Shivers DK, Thomas KA, Chiavacci RM, Hou C, Xu K, Snyder J, Qiu H, Mentch F, Wang K, Winkler CA, Lie BA, Ellis JA, and Hakonarson H. 2016. Variants in CXCR4 associate with juvenile idiopathic arthritis susceptibility. BMC Med Genet 17:24. 10.1186/s12881-016-0285-3

Firestein GS. 2003. Evolving concepts of rheumatoid arthritis. Nature 423:356-361. 10.1038/nature01661

Firestein GS, and McInnes IB. 2017. Immunopathogenesis of Rheumatoid Arthritis. Immunity 46:183-196. https://doi.org/10.1016/j.immuni.2017.02.006

Gianchecchi E, Delfino DV, and Fierabracci A. 2018. NK cells in autoimmune diseases: Linking innate and

Peer] reviewing PDF | (2019:06:38227:2:0:NEW 7 Nov 2019) 
adaptive immune responses. Autoimmun Rev 17:142-154. 10.1016/j.autrev.2017.11.018

Grom AA, Villanueva J, Lee S, Goldmuntz EA, Passo MH, and Filipovich A. 2003. Natural killer cell dysfunction in patients with systemic-onset juvenile rheumatoid arthritis and macrophage activation syndrome. J Pediatr 142:292-296. 10.1067/mpd.2003.110

Hasko G, and Szabo C. 1999. IL-12 as a therapeutic target for pharmacological modulation in immunemediated and inflammatory diseases: regulation of $\mathrm{T}$ helper $1 / \mathrm{T}$ helper 2 responses. $\mathrm{Br} \mathrm{J}$ Pharmacol 127:1295-1304. 10.1038/sj.bjp.0702689

Hinks A, Barton A, Shephard N, Eyre S, Bowes J, Cargill M, Wang E, Ke X, Kennedy GC, John S, Worthington J, and Thomson W. 2009. Identification of a novel susceptibility locus for juvenile idiopathic arthritis by genome-wide association analysis. Arthritis Rheum 60:258-263. 10.1002/art.24179

Hinks A, Cobb J, Marion MC, Prahalad S, Sudman M, Bowes J, Martin P, Comeau ME, Sajuthi S, Andrews R, Brown M, Chen WM, Concannon P, Deloukas P, Edkins S, Eyre S, Gaffney PM, Guthery SL, Guthridge JM, Hunt SE, James JA, Keddache M, Moser KL, Nigrovic PA, Onengut-Gumuscu S, Onslow ML, Rose CD, Rich SS, Steel KJ, Wakeland EK, Wallace CA, Wedderburn LR, Woo P, Bohnsack JF, Haas JP, Glass DN, Langefeld CD, Thomson W, and Thompson SD. 2013. Dense genotyping of immune-related disease regions identifies 14 new susceptibility loci for juvenile idiopathic arthritis. Nat Genet 45:664-669. 10.1038/ng.2614

Hinks A, Marion MC, Cobb J, Comeau ME, Sudman M, Ainsworth HC, Bowes J, Immunochip JIACf, Becker ML, Bohnsack JF, Haas J-P, Lovell DJ, Mellins ED, Nelson JL, Nordal E, Punaro M, Reed $A M$, Rose CD, Rosenberg AM, Rygg M, Smith SL, Stevens AM, Videm V, Wallace CA, Wedderburn LR, Yarwood A, Yeung RSM, Langefeld CD, Thompson SD, Thomson W, and Prahalad S. 2018. Brief Report: The Genetic Profile of Rheumatoid Factor-Positive Polyarticular Juvenile Idiopathic Arthritis Resembles That of Adult Rheumatoid Arthritis. Arthritis \& Rheumatology 70:957-962. 10.1002/art.40443

Hunter TM, Boytsov NN, Zhang X, Schroeder K, Michaud K, and Araujo AB. 2017. Prevalence of rheumatoid arthritis in the United States adult population in healthcare claims databases, 20042014. Rheumatol Int 37:1551-1557. 10.1007/s00296-017-3726-1

Kanehisa M, Furumichi M, Tanabe M, Sato Y, and Morishima K. 2017. KEGG: new perspectives on genomes, pathways, diseases and drugs. Nucleic Acids Res 45:D353-d361. 10.1093/nar/gkw1092

Kanehisa M, and Goto S. 2000. KEGG: kyoto encyclopedia of genes and genomes. Nucleic Acids Res 28:27-30.

Kanehisa M, Sato Y, Furumichi M, Morishima K, and Tanabe M. 2019. New approach for understanding genome variations in KEGG. Nucleic Acids Res 47:D590-d595. 10.1093/nar/gky962

Li YR, Li J, Zhao SD, Bradfield JP, Mentch FD, Maggadottir SM, Hou C, Abrams DJ, Chang D, Gao F, Guo Y, Wei Z, Connolly JJ, Cardinale CJ, Bakay M, Glessner JT, Li D, Kao C, Thomas KA, Qiu H, Chiavacci RM, Kim CE, Wang F, Snyder J, Richie MD, Flato B, Forre O, Denson LA, Thompson SD, Becker ML, Guthery SL, Latiano A, Perez E, Resnick E, Russell RK, Wilson DC, Silverberg MS, Annese V, Lie BA, Punaro M, Dubinsky MC, Monos DS, Strisciuglio C, Staiano A, Miele E, Kugathasan S, Ellis JA, Munro JE, Sullivan KE, Wise CA, Chapel H, Cunningham-Rundles C, Grant SF, Orange JS, Sleiman PM, Behrens EM, Griffiths AM, Satsangi J, Finkel TH, Keinan A, Prak ET, Polychronakos C, Baldassano RN, Li H, Keating BJ, and Hakonarson H. 2015a. Metaanalysis of shared genetic architecture across ten pediatric autoimmune diseases. Nat Med 21:1018-1027. 10.1038/nm.3933

Li YR, Zhao SD, Li J, Bradfield JP, Mohebnasab M, Steel L, Kobie J, Abrams DJ, Mentch FD, Glessner JT, Guo Y, Wei Z, Connolly JJ, Cardinale CJ, Bakay M, Li D, Maggadottir SM, Thomas KA, Qui H, Chiavacci RM, Kim CE, Wang F, Snyder J, Flato B, Forre O, Denson LA, Thompson SD, Becker ML, Guthery SL, Latiano A, Perez E, Resnick E, Strisciuglio C, Staiano A, Miele E, Silverberg MS, Lie BA, Punaro M, Russell RK, Wilson DC, Dubinsky MC, Monos DS, Annese V, Munro JE, Wise C, Chapel H, Cunningham-Rundles C, Orange JS, Behrens EM, Sullivan KE, Kugathasan S, Griffiths AM, Satsangi J, Grant SF, Sleiman PM, Finkel TH, Polychronakos C, Baldassano RN, Luning Prak ET, Ellis JA, Li H, Keating BJ, and Hakonarson H. 2015b. Genetic sharing and heritability of paediatric age of onset autoimmune diseases. Nat Commun 6:8442. 10.1038/ncomms9442

Liberzon A, Birger C, Thorvaldsdóttir H, Ghandi M, Mesirov Jill P, and Tamayo P. 2015. The Molecular 
Signatures Database Hallmark Gene Set Collection. Cell Systems 1:417-425. https://doi.org/10.1016/j.cels.2015.12.004

Liberzon A, Subramanian A, Pinchback R, Thorvaldsdóttir H, Tamayo P, and Mesirov JP. 2011. Molecular signatures database (MSigDB) 3.0. Bioinformatics 27:1739-1740. 10.1093/bioinformatics/btr260 \%J Bioinformatics

Liu J, Cao S, Kim S, Chung EY, Homma Y, Guan X, Jimenez V, and Ma X. 2005. Interleukin-12: an update on its immunological activities, signaling and regulation of gene expression. Current immunology reviews 1:119-137.

Liu JZ, McRae AF, Nyholt DR, Medland SE, Wray NR, Brown KM, Investigators A, Hayward NK, Montgomery GW, Visscher PM, Martin NG, and Macgregor S. 2010. A versatile gene-based test for genome-wide association studies. Am J Hum Genet 87:139-145. 10.1016/j.ajhg.2010.06.009

Mellins ED, Macaubas C, and Grom AA. 2011. Pathogenesis of systemic juvenile idiopathic arthritis: some answers, more questions. Nature Reviews Rheumatology 7:416. 10.1038/nrrheum.2011.68

Nigrovic PA, Raychaudhuri S, and Thompson SD. 2018. Review: Genetics and the Classification of Arthritis in Adults and Children. Arthritis \& Rheumatology 70:7-17. 10.1002/art.40350

Nishimura D. 2001. BioCarta. Biotech Software \& Internet Report 2:117-120. 10.1089/152791601750294344

O. Hersh A, and Prahalad S. 2015. Immunogenetics of juvenile idiopathic arthritis: A comprehensive review. Journal of Autoimmunity 64:113-124. 10.1016/j.jaut.2015.08.002

Okada Y, Wu D, Trynka G, Raj T, Terao C, Ikari K, Kochi Y, Ohmura K, Suzuki A, Yoshida S, Graham RR, Manoharan A, Ortmann W, Bhangale T, Denny JC, Carroll RJ, Eyler AE, Greenberg JD, Kremer JM, Pappas DA, Jiang L, Yin J, Ye L, Su DF, Yang J, Xie G, Keystone E, Westra HJ, Esko T, Metspalu A, Zhou X, Gupta N, Mirel D, Stahl EA, Diogo D, Cui J, Liao K, Guo MH, Myouzen K, Kawaguchi T, Coenen MJ, van Riel PL, van de Laar MA, Guchelaar HJ, Huizinga TW, Dieude P, Mariette X, Bridges SL, Jr., Zhernakova A, Toes RE, Tak PP, Miceli-Richard C, Bang SY, Lee HS, Martin J, Gonzalez-Gay MA, Rodriguez-Rodriguez L, Rantapaa-Dahlqvist S, Arlestig L, Choi HK, Kamatani Y, Galan P, Lathrop M, Eyre S, Bowes J, Barton A, de Vries N, Moreland LW, Criswell LA, Karlson EW, Taniguchi A, Yamada R, Kubo M, Liu JS, Bae SC, Worthington J, Padyukov L, Klareskog L, Gregersen PK, Raychaudhuri S, Stranger BE, De Jager PL, Franke L, Visscher PM, Brown MA, Yamanaka H, Mimori T, Takahashi A, Xu H, Behrens TW, Siminovitch KA, Momohara S, Matsuda F, Yamamoto K, and Plenge RM. 2014. Genetics of rheumatoid arthritis contributes to biology and drug discovery. Nature 506:376-381. 10.1038/nature12873

Ombrello MJ, Arthur VL, Remmers EF, Hinks A, Tachmazidou I, Grom AA, Foell D, Martini A, Gattorno M, Ozen S, Prahalad S, Zeft AS, Bohnsack JF, llowite NT, Mellins ED, Russo R, Len C, Hilario MO, Oliveira S, Yeung RS, Rosenberg AM, Wedderburn LR, Anton J, Haas JP, Rosen-Wolff A, Minden K, Tenbrock K, Demirkaya E, Cobb J, Baskin E, Signa S, Shuldiner E, Duerr RH, Achkar JP, Kamboh MI, Kaufman KM, Kottyan LC, Pinto D, Scherer SW, Alarcon-Riquelme ME, Docampo E, Estivill X, Gul A, Langefeld CD, Thompson S, Zeggini E, Kastner DL, Woo P, and Thomson W. 2017. Genetic architecture distinguishes systemic juvenile idiopathic arthritis from other forms of juvenile idiopathic arthritis: clinical and therapeutic implications. Ann Rheum Dis 76:906-913. 10.1136/annrheumdis-2016-210324

Onuora S. 2018. Genetics: Subtype of JIA is genetically similar to adult RA. Nature Reviews Rheumatology 14:181-181. 10.1038/nrrheum.2018.30

Petty RE, Southwood TR, Manners P, Baum J, Glass DN, Goldenberg J, He X, Maldonado-Cocco J, Orozco-Alcala J, Prieur AM, Suarez-Almazor ME, and Woo P. 2004. International League of Associations for Rheumatology classification of juvenile idiopathic arthritis: second revision, Edmonton, 2001. J Rheumatol 31:390-392.

Plenge RM, Padyukov L, Remmers EF, Purcell S, Lee AT, Karlson EW, Wolfe F, Kastner DL, Alfredsson L, Altshuler D, Gregersen PK, Klareskog L, and Rioux JD. 2005. Replication of putative candidategene associations with rheumatoid arthritis in $>4,000$ samples from North America and Sweden: association of susceptibility with PTPN22, CTLA4, and PADI4. Am J Hum Genet 77:1044-1060. $10.1086 / 498651$

Prahalad S. 2006. Genetic analysis of juvenile rheumatoid arthritis: approaches to complex traits. Curr Probl Pediatr Adolesc Health Care 36:83-90. 10.1016/j.cppeds.2005.10.009

Prakken B, Albani S, and Martini A. 2011. Juvenile idiopathic arthritis. The Lancet 377:2138-2149. $10.1016 / \mathrm{s} 0140-6736(11) 60244-4$ 
Purcell S, Neale B, Todd-Brown K, Thomas L, Ferreira MA, Bender D, Maller J, Sklar P, de Bakker PI, Daly MJ, and Sham PC. 2007. PLINK: a tool set for whole-genome association and populationbased linkage analyses. Am J Hum Genet 81:559-575. 10.1086/519795

Ravelli A, and Martini A. 2007. Juvenile idiopathic arthritis. The Lancet 369:767-778. https://doi.org/10.1016/S0140-6736(07)60363-8

Raychaudhuri S, Thomson BP, Remmers EF, Eyre S, Hinks A, Guiducci C, Catanese JJ, Xie G, Stahl EA, Chen R, Alfredsson L, Amos Cl, Ardlie KG, Barton A, Bowes J, Burtt NP, Chang M, Coblyn J, Costenbader KH, Criswell LA, Crusius JB, Cui J, De Jager PL, Ding B, Emery P, Flynn E, Harrison P, Hocking LJ, Huizinga TW, Kastner DL, Ke X, Kurreeman FA, Lee AT, Liu X, Li Y, Martin P, Morgan AW, Padyukov L, Reid DM, Seielstad M, Seldin MF, Shadick NA, Steer S, Tak PP, Thomson W, van der Helm-van Mil AH, van der Horst-Bruinsma IE, Weinblatt ME, Wilson AG, Wolbink GJ, Wordsworth P, Altshuler D, Karlson EW, Toes RE, de Vries N, Begovich AB, Siminovitch KA, Worthington J, Klareskog L, Gregersen PK, Daly MJ, and Plenge RM. 2009. Genetic variants at CD28, PRDM1 and CD2/CD58 are associated with rheumatoid arthritis risk. Nat Genet 41:1313-1318. 10.1038/ng.479

Schaefer CF, Anthony K, Krupa S, Buchoff J, Day M, Hannay T, and Buetow KH. 2009. PID: the Pathway Interaction Database. Nucleic Acids Research 37:D674-D679. 10.1093/nar/gkn653

Scott DL, Wolfe F, and Huizinga TW. 2010. Rheumatoid arthritis. Lancet 376:1094-1108. 10.1016/s01406736(10)60826-4

Siebert S, Tsoukas A, Robertson J, and McInnes I. 2015. Cytokines as therapeutic targets in rheumatoid arthritis and other inflammatory diseases. Pharmacol Rev 67:280-309. 10.1124/pr.114.009639

Speed D, and Balding DJ. 2014. MultiBLUP: improved SNP-based prediction for complex traits. Genome Res 24:1550-1557. 10.1101/gr.169375.113

Speed D, Hemani G, Johnson MR, and Balding DJ. 2012. Improved heritability estimation from genomewide SNPs. Am J Hum Genet 91:1011-1021. 10.1016/j.ajhg.2012.10.010

Subramanian A, Tamayo P, Mootha VK, Mukherjee S, Ebert BL, Gillette MA, Paulovich A, Pomeroy SL, Golub TR, Lander ES, and Mesirov JP. 2005. Gene set enrichment analysis: A knowledge-based approach for interpreting genome-wide expression profiles. Proceedings of the National Academy of Sciences 102:15545-15550. 10.1073/pnas.0506580102

Szklarczyk D, Franceschini A, Wyder S, Forslund K, Heller D, Huerta-Cepas J, Simonovic M, Roth A, Santos A, Tsafou KP, Kuhn M, Bork P, Jensen LJ, and von Mering C. 2015. STRING v10: proteinprotein interaction networks, integrated over the tree of life. Nucleic Acids Res 43:D447-452. 10.1093/nar/gku1003

The Genomes Project C, Auton A, Abecasis GR, Altshuler DM, Durbin RM, Abecasis GR, Bentley DR, Chakravarti A, Clark AG, Donnelly P, Eichler EE, Flicek P, Gabriel SB, Gibbs RA, Green ED, Hurles ME, Knoppers BM, Korbel JO, Lander ES, Lee C, Lehrach H, Mardis ER, Marth GT, McVean GA, Nickerson DA, Schmidt JP, Sherry ST, Wang J, Wilson RK, Gibbs RA, Boerwinkle E, Doddapaneni H, Han Y, Korchina V, Kovar C, Lee S, Muzny D, Reid JG, Zhu Y, Wang J, Chang Y, Feng Q, Fang X, Guo X, Jian M, Jiang H, Jin X, Lan T, Li G, Li J, Li Y, Liu S, Liu X, Lu Y, Ma X, Tang M, Wang B, Wang G, Wu H, Wu R, Xu X, Yin Y, Zhang D, Zhang W, Zhao J, Zhao M, Zheng X, Lander ES, Altshuler DM, Gabriel SB, Gupta N, Gharani N, Toji LH, Gerry NP, Resch AM, Flicek P, Barker J, Clarke L, Gil L, Hunt SE, Kelman G, Kulesha E, Leinonen R, McLaren WM, Radhakrishnan R, Roa A, Smirnov D, Smith RE, Streeter I, Thormann A, Toneva I, Vaughan B, Zheng-Bradley X, Bentley DR, Grocock R, Humphray S, James T, Kingsbury Z, Lehrach H, Sudbrak R, Albrecht MW, Amstislavskiy VS, Borodina TA, Lienhard M, Mertes F, Sultan M, Timmermann B, Yaspo M-L, Mardis ER, Wilson RK, Fulton L, Fulton R, Sherry ST, Ananiev V, Belaia Z, Beloslyudtsev D, Bouk N, Chen C, Church D, Cohen R, Cook C, Garner J, Hefferon T, Kimelman M, Liu C, Lopez J, Meric P, O'Sullivan C, Ostapchuk Y, Phan L, Ponomarov S, Schneider V, Shekhtman E, Sirotkin K, Slotta D, Zhang H, McVean GA, Durbin RM, Balasubramaniam S, Burton J, Danecek P, Keane TM, Kolb-Kokocinski A, McCarthy S, Stalker J, Quail M, Schmidt JP, Davies CJ, Gollub J, Webster T, Wong B, Zhan Y, Auton A, Campbell CL, Kong Y, Marcketta A, Gibbs RA, Yu F, Antunes L, Bainbridge M, Muzny D, Sabo A, Huang Z, Wang J, Coin LJM, Fang L, Guo X, Jin X, Li G, Li Q, Li Y, Li Z, Lin H, Liu B, Luo R, Shao H, Xie Y, Ye C, Yu C, Zhang F, Zheng H, Zhu H, Alkan C, Dal E, Kahveci F, Marth GT, Garrison EP, Kural D, Lee W-P, Fung Leong W, Stromberg M, Ward AN, Wu J, Zhang M, Daly MJ, DePristo MA, Handsaker RE, Altshuler DM, Banks E, Bhatia G, del Angel G, Gabriel SB, Genovese G, Gupta N, 
Li H, Kashin S, Lander ES, McCarroll SA, Nemesh JC, Poplin RE, Yoon SC, Lihm J, Makarov V, Clark AG, Gottipati S, Keinan A, Rodriguez-Flores JL, Korbel JO, Rausch T, Fritz MH, Stütz AM, Flicek P, Beal K, Clarke L, Datta A, Herrero J, McLaren WM, Ritchie GRS, Smith RE, Zerbino D, Zheng-Bradley X, Sabeti PC, Shlyakhter I, Schaffner SF, Vitti J, Cooper DN, Ball EV, Stenson PD, Bentley DR, Barnes B, Bauer M, Keira Cheetham R, Cox A, Eberle M, Humphray S, Kahn S, Murray L, Peden J, Shaw R, Kenny EE, Batzer MA, Konkel MK, Walker JA, MacArthur DG, Lek M, Sudbrak R, Amstislavskiy VS, Herwig R, Mardis ER, Ding L, Koboldt DC, Larson D, Ye K, Gravel S, Swaroop A, Chew E, Lappalainen T, Erlich Y, Gymrek M, Frederick Willems T, Simpson JT, Shriver MD, Rosenfeld JA, Bustamante CD, Montgomery SB, De La Vega FM, Byrnes JK, Carroll AW, DeGorter MK, Lacroute P, Maples BK, Martin AR, Moreno-Estrada A, Shringarpure SS, Zakharia F, Halperin E, Baran Y, Lee C, Cerveira E, Hwang J, Malhotra A, Plewczynski D, Radew K, Romanovitch M, Zhang C, Hyland FCL, Craig DW, Christoforides A, Homer N, Izatt T, Kurdoglu AA, Sinari SA, Squire K, Sherry ST, Xiao C, Sebat J, Antaki D, Gujral M, Noor A, Ye K, Burchard EG, Hernandez RD, Gignoux CR, Haussler D, Katzman SJ, James Kent W, Howie B, Ruiz-Linares A, Dermitzakis ET, Devine SE, Abecasis GR, Min Kang H, Kidd JM, Blackwell T, Caron S, Chen W, Emery S, Fritsche L, Fuchsberger C, Jun G, Li B, Lyons R, Scheller C, Sidore C, Song S, Sliwerska E, Taliun D, Tan A, Welch R, Kate Wing M, Zhan X, Awadalla P, Hodgkinson A, Li Y, Shi X, Quitadamo A, Lunter G, McVean GA, Marchini JL, Myers S, Churchhouse C, Delaneau O, Gupta-Hinch A, Kretzschmar W, Iqbal Z, Mathieson I, Menelaou A, Rimmer A, Xifara DK, Oleksyk TK, Fu Y, Liu X, Xiong M, Jorde L, Witherspoon D, Xing J, Eichler EE, Browning BL, Browning SR, Hormozdiari F, Sudmant PH, Khurana E, Durbin RM, Hurles ME, Tyler-Smith C, Albers CA, Ayub $Q$, Balasubramaniam S, Chen Y, Colonna V, Danecek P, Jostins L, Keane TM, McCarthy S, Walter K, Xue Y, Gerstein MB, Abyzov A, Balasubramanian S, Chen J, Clarke D, Fu Y, Harmanci AO, Jin M, Lee D, Liu J, Jasmine Mu X, Zhang J, Zhang Y, Li Y, Luo R, Zhu H, Alkan C, Dal E, Kahveci F, Marth GT, Garrison EP, Kural D, Lee W-P, Ward AN, Wu J, Zhang M, McCarroll SA, Handsaker RE, Altshuler DM, Banks E, del Angel G, Genovese G, Hartl C, Li H, Kashin S, Nemesh JC, Shakir K, Yoon SC, Lihm J, Makarov V, Degenhardt J, Korbel JO, Fritz MH, Meiers S, Raeder B, Rausch T, Stütz AM, Flicek P, Paolo Casale F, Clarke L, Smith RE, Stegle O, ZhengBradley X, Bentley DR, Barnes B, Keira Cheetham R, Eberle M, Humphray S, Kahn S, Murray L, Shaw R, Lameijer E-W, Batzer MA, Konkel MK, Walker JA, Ding L, Hall I, Ye K, Lacroute P, Lee C, Cerveira E, Malhotra A, Hwang J, Plewczynski D, Radew K, Romanovitch M, Zhang C, Craig DW, Homer N, Church D, Xiao C, Sebat J, Antaki D, Bafna V, Michaelson J, Ye K, Devine SE, Gardner EJ, Abecasis GR, Kidd JM, Mills RE, Dayama G, Emery S, Jun G, Shi X, Quitadamo A, Lunter G, McVean GA, Chen K, Fan X, Chong Z, Chen T, Witherspoon D, Xing J, Eichler EE, Chaisson MJ, Hormozdiari F, Huddleston J, Malig M, Nelson BJ, Sudmant PH, Parrish NF, Khurana E, Hurles ME, Blackburne B, Lindsay SJ, Ning Z, Walter K, Zhang Y, Gerstein MB, Abyzov A, Chen J, Clarke D, Lam H, Jasmine Mu X, Sisu C, Zhang J, Zhang Y, Gibbs RA, Yu F, Bainbridge M, Challis D, Evani US, Kovar C, Lu J, Muzny D, Nagaswamy U, Reid JG, Sabo A, Yu J, Guo X, Li W, Li Y, Wu R, Marth GT, Garrison EP, Fung Leong W, Ward AN, del Angel G, DePristo MA, Gabriel SB, Gupta N, Hartl C, Poplin RE, Clark AG, Rodriguez-Flores JL, Flicek P, Clarke L, Smith RE, Zheng-Bradley X, MacArthur DG, Mardis ER, Fulton R, Koboldt DC, Gravel S, Bustamante CD, Craig DW, Christoforides A, Homer N, Izatt T, Sherry ST, Xiao C, Dermitzakis ET, Abecasis GR, Min Kang H, McVean GA, Gerstein MB, Balasubramanian S, Habegger L, Yu H, Flicek P, Clarke L, Cunningham F, Dunham I, Zerbino D, Zheng-Bradley X, Lage K, Berg Jespersen J, Horn H, Montgomery SB, DeGorter MK, Khurana E, Tyler-Smith C, Chen Y, Colonna V, Xue Y, Gerstein MB, Balasubramanian S, Fu Y, Kim D, Auton A, Marcketta A, Desalle R, Narechania A, Wilson Sayres MA, Garrison EP, Handsaker RE, Kashin S, McCarroll SA, Rodriguez-Flores JL, Flicek P, Clarke L, Zheng-Bradley X, Erlich Y, Gymrek M, Frederick Willems T, Bustamante CD, Mendez FL, David Poznik G, Underhill PA, Lee C, Cerveira E, Malhotra A, Romanovitch M, Zhang C, Abecasis GR, Coin L, Shao H, Mittelman D, Tyler-Smith C, Ayub Q, Banerjee R, Cerezo M, Chen Y, Fitzgerald TW, Louzada S, Massaia A, McCarthy S, Ritchie GR, Xue Y, Yang F, Gibbs RA, Kovar C, Kalra D, Hale W, Muzny D, Reid JG, Wang J, Dan X, Guo X, Li G, Li Y, Ye C, Zheng X, Altshuler DM, Flicek P, Clarke L, Zheng-Bradley X, Bentley DR, Cox A, Humphray S, Kahn S, Sudbrak R, Albrecht MW, Lienhard M, Larson D, Craig DW, Izatt T, Kurdoglu AA, Sherry ST, Xiao C, Haussler D, Abecasis GR, McVean GA, Durbin RM, Balasubramaniam S, Keane TM, McCarthy S, Stalker J, Chakravarti A, Knoppers BM, Abecasis GR, Barnes KC, Beiswanger C, Burchard EG, 
Bustamante CD, Cai H, Cao H, Durbin RM, Gerry NP, Gharani N, Gibbs RA, Gignoux CR, Gravel S, Henn B, Jones D, Jorde L, Kaye JS, Keinan A, Kent A, Kerasidou A, Li Y, Mathias R, McVean GA, Moreno-Estrada A, Ossorio PN, Parker M, Resch AM, Rotimi CN, Royal CD, Sandoval K, Su Y, Sudbrak R, Tian Z, Tishkoff S, Toji LH, Tyler-Smith C, Via M, Wang Y, Yang H, Yang L, Zhu J, Bodmer W, Bedoya G, Ruiz-Linares A, Cai Z, Gao Y, Chu J, Peltonen L, Garcia-Montero A, Orfao A, Dutil J, Martinez-Cruzado JC, Oleksyk TK, Barnes KC, Mathias RA, Hennis A, Watson H, McKenzie C, Qadri F, LaRocque R, Sabeti PC, Zhu J, Deng X, Sabeti PC, Asogun D, Folarin O, Happi C, Omoniwa O, Stremlau M, Tariyal R, Jallow M, Sisay Joof F, Corrah T, Rockett K, Kwiatkowski D, Kooner J, Tịnh Hiê`n Tn, Dunstan SJ, Thuy Hang N, Fonnie R, Garry R, Kanneh L, Moses L, Sabeti PC, Schieffelin J, Grant DS, Gallo C, Poletti G, Saleheen D, Rasheed A, Brooks LD, Felsenfeld AL, McEwen JE, Vaydylevich Y, Green ED, Duncanson A, Dunn M, Schloss JA, Wang J, Yang H, Auton A, Brooks LD, Durbin RM, Garrison EP, Min Kang H, Korbel JO, Marchini JL, McCarthy S, McVean GA, and Abecasis GR. 2015. A global reference for human genetic variation. Nature 526:68. 10.1038/nature15393

https://www.nature.com/articles/nature15393\#supplementary-information

Thierry S, Fautrel B, Lemelle I, and Guillemin F. 2014. Prevalence and incidence of juvenile idiopathic arthritis: a systematic review. Joint Bone Spine 81:112-117. 10.1016/j.jbspin.2013.09.003

Thompson SD, Marion MC, Sudman M, Ryan M, Tsoras M, Howard TD, Barnes MG, Ramos PS, Thomson W, Hinks A, Haas JP, Prahalad S, Bohnsack JF, Wise CA, Punaro M, Rose CD, Pajewski NM, Spigarelli M, Keddache M, Wagner M, Langefeld CD, and Glass DN. 2012. Genome-wide association analysis of juvenile idiopathic arthritis identifies a new susceptibility locus at chromosomal region 3q13. Arthritis Rheum 64:2781-2791. 10.1002/art.34429

Viatte S, Plant D, and Raychaudhuri S. 2013. Genetics and epigenetics of rheumatoid arthritis. Nature Reviews Rheumatology 9:141. 10.1038/nrrheum.2012.237

Yamin R, Berhani O, Peleg H, Aamar S, Stein N, Gamliel M, Hindi I, Scheiman-Elazary A, and Gur C. 2019. High percentages and activity of synovial fluid NK cells present in patients with advanced stage active Rheumatoid Arthritis. Sci Rep 9:1351. 10.1038/s41598-018-37448-z

Yang J, Lee SH, Goddard ME, and Visscher PM. 2011. GCTA: A Tool for Genome-wide Complex Trait Analysis. The American Journal of Human Genetics 88:76-82. https://doi.org/10.1016/j.ajhg.2010.11.011

Yoon S, Nguyen HCT, Yoo YJ, Kim J, Baik B, Kim S, Kim J, Kim S, and Nam D. 2018. Efficient pathway enrichment and network analysis of GWAS summary data using GSA-SNP2. Nucleic Acids Research 46:e60. 10.1093/nar/gky175

Yoshida H, and Miyazaki Y. 2008. Regulation of immune responses by interleukin-27. Immunol Rev 226:234-247. 10.1111/j.1600-065X.2008.00710.x

Zhu H, Xia W, Mo XB, Lin X, Qiu YH, Yi NJ, Zhang YH, Deng FY, and Lei SF. 2016. Gene-Based Genome-Wide Association Analysis in European and Asian Populations Identified Novel Genes for Rheumatoid Arthritis. PLoS One 11:e0167212. 10.1371/journal.pone.0167212

\section{Figure legends:}

Figure 1 The global network of RA after the HLA region being removed. (Q-value $<0.05$, genescore $<0.005)$

The PPI network was constructed among proteins encoded by the significant RA-associated genes excluding those in the HLA region. The nodes in the figure represent the proteins and the connections between nodes indicate protein-protein interactions. The size of each node suggests the degrees of the connection between the node and the others. 
593 Figure 2 The global network of JIA after the HLA region being removed. (Q-value $<0.05$, gene594 score $<0.005)$

595 The PPI network was constructed among proteins encoded by the significant JIA-associated 596 genes excluding those in the HLA region. The nodes in the figure represent the proteins and the 597 connections between nodes indicate protein-protein interactions. The size of each node suggests 598 the degrees of the connection between the node and the others. 
Figure 1

The global network of RA after the HLA region being removed. (Q-value $<0.05$, genescore $<0.005$ )

The PPI network was constructed among proteins encoded by the significant RA-associated genes excluding those in the HLA region. The nodes in the figure represent the proteins and the connections between nodes indicate protein-protein interactions. The size of each node suggests the degrees of the connection between the node and the others. 


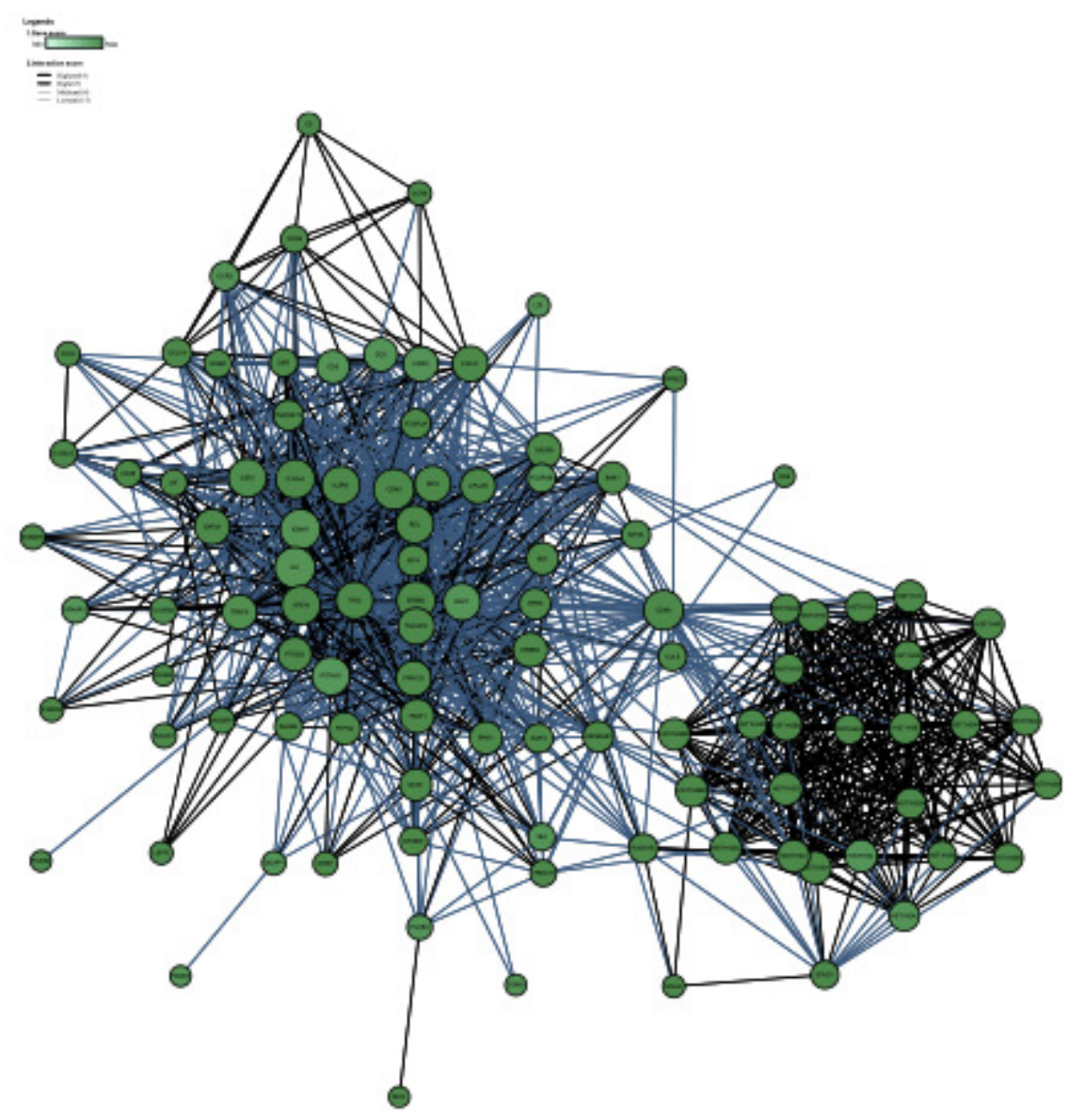




\section{Figure 2}

The global network of JIA after the HLA region being removed. (Q-value $<0.05$, genescore $<0.005$ )

The PPI network was constructed among proteins encoded by the significant JIA-associated genes excluding those in the HLA region. The nodes in the figure represent the proteins and the connections between nodes indicate protein-protein interactions. The size of each node suggests the degrees of the connection between the node and the others. 


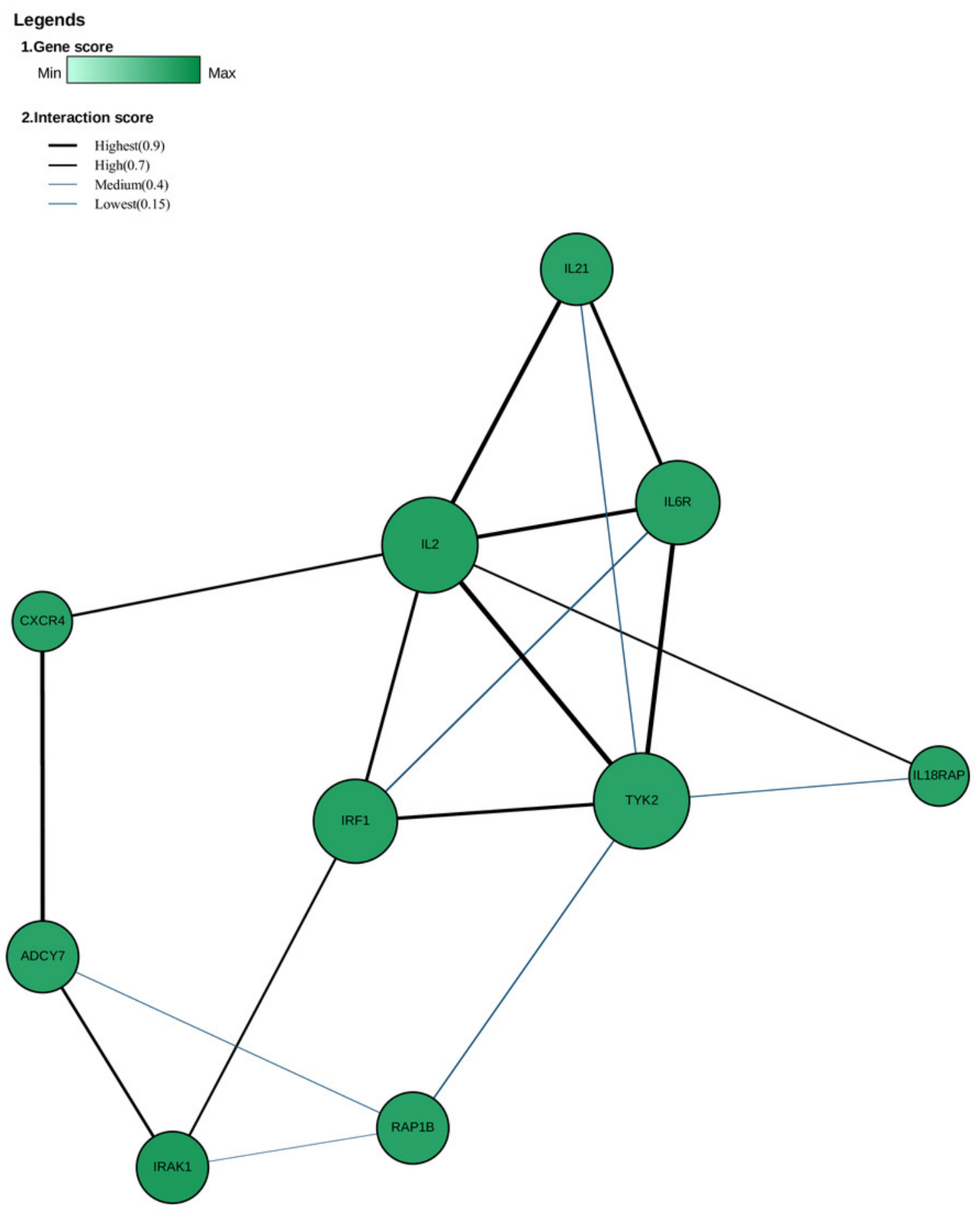




\section{Table $\mathbf{1}$ (on next page)}

Genome-wide significant SNPs shared by RA and JIA $\left(\mathrm{P}\right.$-value $\left.<5 \times 10^{-8}\right)$.

The raw data of genome-wide significant SNPs of RA are presented in Table S1; and the raw data of genome-wide significant SNPS of JIA are shown in and Table S2 and Table S3. SNP = single nucleotide polymorphism; $\mathrm{Chr}=$ chromosome; Pos $=$ position on human genome build hg19 (NCBI GRCh37); RA = rheumatoid arthritis; JIA = juvenile idiopathic arthritis; Allele = risk allele; $\mathrm{OR}=$ odds ratio of risk allele; Pval = disease association P-value of risk SNP; RefSeq gene $=$ the closest gene to each SNP and their relative positions based on Reference sequence (RefSeq) database (O'Leary et al. 2016). 
1 Table 1:

2 Genome-wide significant SNPs shared by RA and JIA (P-value $\left.<5 \times 10^{-8}\right)$

3 The raw data of genome-wide significant SNPs of RA are presented in Table S1; and the raw

4 data of genome-wide significant SNPs of JIA are shown in and Table S2 and Table S3.

$5 \mathrm{SNP}=$ single nucleotide polymorphism; $\mathrm{Chr}=$ chromosome; $\mathrm{Pos}=$ position on human genome

6 build hg19 (NCBI GRCh37); RA = rheumatoid arthritis; JIA = juvenile idiopathic arthritis;

7 Allele $=$ risk allele; OR $=$ odds ratio of risk allele; Pval = disease association P-value of risk SNP;

8 RefSeq gene $=$ the closest gene to each SNP and their relative positions based on Reference

9 sequence (RefSeq) database (O'Leary et al. 2016).

10

\begin{tabular}{|c|c|c|c|c|c|c|c|c|c|}
\hline \multirow[b]{2}{*}{ SNP } & \multirow[b]{2}{*}{ Chr } & \multirow[b]{2}{*}{ Pos } & \multicolumn{3}{|c|}{$\mathbf{R A}$} & \multicolumn{3}{|c|}{ JIA } & \multirow[b]{2}{*}{ RefSeq gene } \\
\hline & & & Allele & OR & Pval & Allele & OR & Pval & \\
\hline rs6679677 & 1 & 114303808 & A & 1.81 & $2.1 \mathrm{E}-149$ & A & 1.59 & $3 \mathrm{E}-25$ & $644 \mathrm{bp} 3^{\prime}$ of $R S B N 1$ \\
\hline rs 10174238 & 2 & 191973034 & $\mathrm{G}$ & 1.14 & $1.2 \mathrm{E}-13$ & $\mathrm{G}$ & 1.29 & $1 \mathrm{E}-13$ & STAT4 \\
\hline rs 10213692 & 5 & 55442249 & $\mathrm{~T}$ & 1.19 & $1.3 \mathrm{E}-17$ & & 1.27 & $3 \mathrm{E}-11$ & $A N K R D 55$ \\
\hline rs 7731626 & 5 & 55444683 & $\mathrm{G}$ & 1.20 & $7.3 \mathrm{E}-24$ & A & & $1 \mathrm{E}-10$ & $A N K R D 55$ \\
\hline rs2517930 & 6 & 29745075 & $\mathrm{~T}$ & 1.18 & $1.7 \mathrm{E}-31$ & $\mathrm{~T}$ & 1.47 & $8.95 \mathrm{E}-11$ & $14 \mathrm{~kb} 3^{\prime}$ of $H C G 4$ \\
\hline rs2975033 & 6 & 29822261 & $\mathrm{~A}$ & 1.18 & $1.6 \mathrm{E}-33$ & $\mathrm{~A}$ & 1.47 & $6.48 \mathrm{E}-10$ & $23 \mathrm{~kb} 3$ ' of the HLA-G \\
\hline rs 12206499 & 6 & 29937127 & $\mathrm{G}$ & 1.16 & $6.4 \mathrm{E}-26$ & G & 1.41 & $3.59 \mathrm{E}-08$ & $5.8 \mathrm{~kb} 5^{\prime}$ of $H C G 9$ \\
\hline rs3823355 & 6 & 29942083 & $\mathrm{~T}$ & 1.16 & $6.5 \mathrm{E}-26$ & $\mathrm{~T}$ & 1.43 & $1.10 \mathrm{E}-08$ & $807 \mathrm{bp} 5^{\prime}$ of $H C G 9$ \\
\hline rs6904029 & 6 & 29943067 & $\mathrm{~A}$ & 1.16 & $6.8 \mathrm{E}-26$ & $\mathrm{~A}$ & 1.43 & $1.44 \mathrm{E}-08$ & HCG9 \\
\hline rs3823375 & 6 & 29944158 & $\mathrm{C}$ & 1.16 & $1.7 \mathrm{E}-25$ & $\mathrm{C}$ & 1.44 & $3.10 \mathrm{E}-09$ & HCG9 \\
\hline rs9366752 & 6 & 30024677 & $\mathrm{~T}$ & 1.09 & $1.6 \mathrm{E}-09$ & $\mathrm{~T}$ & 1.51 & $2.97 \mathrm{E}-10$ & ZNRD1-AS1 \\
\hline rs 1265048 & 6 & 31081409 & $\mathrm{C}$ & 1.12 & $5.3 \mathrm{E}-17$ & $\mathrm{C}$ & 1.44 & $2.91 \mathrm{E}-09$ & $1.1 \mathrm{~kb} 5^{\prime}$ of $C 6 o r f 15$ \\
\hline rs 13202464 & 6 & 31344583 & $\mathrm{G}$ & 1.19 & $1.5 \mathrm{E}-15$ & $\mathrm{G}$ & 2.00 & $2.09 \mathrm{E}-11$ & $20 \mathrm{~kb} 5^{\prime}$ of the $H L A-B$ \\
\hline rs9266689 & 6 & 31348580 & $\mathrm{G}$ & 1.14 & $3.3 \mathrm{E}-19$ & $\mathrm{G}$ & 1.54 & $6.16 \mathrm{E}-11$ & $19 \mathrm{~kb} 5^{\prime}$ of $M I C A$ \\
\hline rs 2844533 & 6 & 31350802 & A & 1.30 & $6.6 \mathrm{E}-55$ & A & 1.61 & $2.90 \mathrm{E}-08$ & $17 \mathrm{~kb} 5^{\prime}$ of $M I C A$ \\
\hline rs 2261033 & 6 & 31603591 & $\mathrm{G}$ & 1.56 & $4.2 \mathrm{E}-183$ & $\mathrm{G}$ & 1.48 & $5.09 \mathrm{E}-09$ & $P R R C 2 A$ \\
\hline rs6941112 & 6 & 31946614 & A & 1.31 & $6.1 \mathrm{E}-83$ & A & 1.42 & $3.20 \mathrm{E}-09$ & STK 19 \\
\hline rs8111 & 6 & 32083175 & $\mathrm{~T}$ & 1.33 & $7.2 \mathrm{E}-86$ & $\mathrm{~T}$ & 1.49 & $5.60 \mathrm{E}-11$ & $A T F 6 B$ \\
\hline rs204999 & 6 & 32109979 & $\mathrm{~A}$ & 1.55 & $5.5 \mathrm{E}-134$ & A & 1.53 & $5.88 \mathrm{E}-09$ & $6.2 \mathrm{~kb} 3^{\prime}$ of $P R R T 1$ \\
\hline rs17576984 & 6 & 32212985 & $\mathrm{C}$ & 1.54 & $3.0 \mathrm{E}-72$ & $\mathrm{~T}$ & 1.86 & $1.66 \mathrm{E}-12$ & $21 \mathrm{~kb} 5^{\prime}$ of $\mathrm{NOTCH} 4$ \\
\hline rs570963 & 6 & 32289594 & A & 1.18 & $2.9 \mathrm{E}-18$ & $\mathrm{G}$ & 1.70 & $8.91 \mathrm{E}-11$ & C6orf10 \\
\hline rs910049 & 6 & 32315727 & $\mathrm{C}$ & 1.19 & 5. $2 \mathrm{E}-24$ & $\mathrm{C}$ & 1.65 & $5.48 \mathrm{E}-10$ & C6orf10 \\
\hline rs2395148 & 6 & 32321554 & $\mathrm{G}$ & 1.41 & $1.0 \mathrm{E}-20$ & $\mathrm{~T}$ & 3.62 & $1.08 \mathrm{E}-25$ & C6orf10 \\
\hline rs6907322 & 6 & 32324945 & $\mathrm{G}$ & 1.14 & $1.7 \mathrm{E}-15$ & $\mathrm{~A}$ & 1.69 & $9.99 \mathrm{E}-15$ & C6orf10 \\
\hline rs9268365 & 6 & 32333439 & $\mathrm{G}$ & 1.16 & $1.3 \mathrm{E}-20$ & $\mathrm{~T}$ & 1.66 & $4.98 \mathrm{E}-14$ & C6orf10 \\
\hline rs3129941 & 6 & 32337686 & $\mathrm{G}$ & 1.64 & $1.4 \mathrm{E}-133$ & $\mathrm{G}$ & 1.60 & $1.48 \mathrm{E}-09$ & C6orf10 \\
\hline rs41291794 & 6 & 32425762 & A & 1.65 & $1.1 \mathrm{E}-63$ & & 2.10 & $4 \mathrm{E}-15$ & $13 \mathrm{~kb} 3^{\prime}$ of $H L A-D R A H L A-D R A$ \\
\hline rs2395185 & 6 & 32433167 & $\mathrm{~T}$ & 2.01 & $1.0 \mathrm{E}-250$ & $\mathrm{G}$ & 1.81 & $1.19 \mathrm{E}-16$ & $20 \mathrm{~kb} 3^{\prime}$ of $H L A-D R A H L A-D R A$ \\
\hline rs477515 & 6 & 32569691 & A & 1.99 & $1.0 \mathrm{E}-250$ & $\mathrm{G}$ & 1.89 & $3.19 \mathrm{E}-18$ & $12 \mathrm{~kb} 5^{\prime}$ of $H L A-D R B 1 H L A-D R B 1$ \\
\hline rs 2516049 & 6 & 32570400 & $\mathrm{C}$ & 2.00 & $1.0 \mathrm{E}-250$ & $\mathrm{~T}$ & 1.89 & $2.62 \mathrm{E}-18$ & $13 \mathrm{~kb} 5^{\prime}$ of $H L A-D R B 1 H L A-D R B 1$ \\
\hline rs 2858870 & 6 & 32572251 & $\mathrm{~T}$ & 1.86 & $1.1 \mathrm{E}-77$ & $\mathrm{~T}$ & 2.19 & $8.41 \mathrm{E}-12$ & $15 \mathrm{~kb} 5^{\prime}$ of $H L A-D R B 1 H L A-D R B 1$ \\
\hline rs 7775055 & 6 & 32657916 & $\mathrm{C}$ & 1.56 & $1.4 \mathrm{E}-60$ & $\mathrm{C}$ & 6.01 & $3 \mathrm{E}-174$ & $23 \mathrm{~kb} 5^{\prime}$ of $H L A-D Q B 1 H L A-D Q B 1$ \\
\hline rs9275224 & 6 & 32659878 & $\mathrm{G}$ & 2.13 & $1.0 \mathrm{E}-250$ & $\mathrm{G}$ & 1.41 & $1.06 \mathrm{E}-08$ & $25 \mathrm{~kb} 5^{\prime}$ of $H L A-D Q B 1$ HLA-DQB1 \\
\hline rs6457617 & 6 & 32663851 & $\mathrm{~T}$ & 2.14 & $1.0 \mathrm{E}-250$ & $\mathrm{~T}$ & 1.40 & $1.10 \mathrm{E}-08$ & $29 \mathrm{~kb} 5^{\prime}$ of $H L A-D O B 1 H L A-D O B 1$ \\
\hline rs2858308 & 6 & 32670000 & $\mathrm{G}$ & 1.61 & $7.8 \mathrm{E}-92$ & $\mathrm{G}$ & 1.98 & $1.94 \mathrm{E}-08$ & $36 \mathrm{~kb} 5^{\prime}$ of $H L A-D Q B 1 H L A-D Q B 1$ \\
\hline rs2856705 & 6 & 32670956 & $\mathrm{C}$ & 1.61 & $1.0 \mathrm{E}-91$ & $\mathrm{C}$ & 1.99 & $1.64 \mathrm{E}-08$ & $36 \mathrm{~kb} 5^{\prime}$ of $H L A-D O B 1 H L A-D O B 1$ \\
\hline rs13192471 & 6 & 32671103 & $\mathrm{C}$ & 1.49 & $4.8 \mathrm{E}-123$ & $\mathrm{C}$ & 1.93 & $1.93 \mathrm{E}-19$ & $37 \mathrm{~kb} 5^{\prime}$ of $H L A-D Q B 1 H L A-D O B 1$ \\
\hline rs 1794275 & 6 & 32671248 & A & 1.33 & $3.7 \mathrm{E}-69$ & A & 1.82 & $3.47 \mathrm{E}-13$ & $37 \mathrm{~kb} 5^{\prime}$ of $H L A-D O B 1 H L A-D O B 1$ \\
\hline rs 7765379 & 6 & 32680928 & $\mathrm{G}$ & 1.89 & $1.0 \mathrm{E}-250$ & $\mathrm{G}$ & 1.68 & $3.11 \mathrm{E}-10$ & $28 \mathrm{~kb} 5^{\prime}$ of $H L A-D O B 1$ HLA-DOA2 \\
\hline rs4713610 & 6 & 33107955 & $\mathrm{G}$ & 1.27 & $5.7 \mathrm{E}-49$ & $\mathrm{G}$ & 1.54 & $7.54 \mathrm{E}-09$ & $11 \mathrm{~kb} 3^{\prime}$ of $H L A-D O B 1 H L A-D P B 2$ \\
\hline rs9277912 & 6 & 33124658 & $\mathrm{~T}$ & 1.26 & $1.1 \mathrm{E}-48$ & $\mathrm{~T}$ & 1.51 & $2.61 \mathrm{E}-08$ & $5.8 \mathrm{~kb} 3^{\prime}$ of $C O L 11 A 2$ \\
\hline rs 706778 & 10 & 6098949 & $\mathrm{~T}$ & 1.09 & $1.5 \mathrm{E}-10$ & $\mathrm{~T}$ & & $6 \mathrm{E}-09$ & $I L 2 R A$ \\
\hline rs9532434 & 13 & 40355913 & $\mathrm{C}$ & 1.10 & $1.0 \mathrm{E}-11$ & & 1.19 & $5 \mathrm{E}-08$ & COG6 \\
\hline rs3825568 & 14 & 69260588 & $\mathrm{~T}$ & 1.08 & $2.7 \mathrm{E}-08$ & & 1.30 & $1 \mathrm{E}-08$ & $802 \mathrm{bp} 5^{\prime}$ of $Z F P 36 L 1$ \\
\hline rs2847293 & 18 & 12782448 & A & 1.12 & $1.2 \mathrm{E}-10$ & A & 1.31 & $1 \mathrm{E}-12$ & $3 \mathrm{~kb} 3^{\prime}$ of $P T P N 2$ \\
\hline rs34536443 & 19 & 10463118 & $\mathrm{G}$ & 1.46 & $4.4 \mathrm{E}-16$ & & 1.79 & $1 \mathrm{E}-10$ & $T Y K 2$ \\
\hline rs 8129030 & 21 & 36712588 & A & 1.09 & $2.5 \mathrm{E}-09$ & & 1.28 & $5 E-09$ & $291 \mathrm{~kb} 5^{\prime}$ of $R U N X 1$ \\
\hline
\end{tabular}




\section{Table 2 (on next page)}

Genome-wide significant genes outside the HLA region shared by RA and JIA (genebased P-value $<2 \times 10^{-6}$ ).

The raw data of genome-wide significant genes of RA are shown in Table S4 and those of JIA are shown in Table S3 and Table S5. Chr = chromosome; Start-End = Start and end boundaries of the gene region in human genome build UCSC hg19 (NCBI GRCh37); RA = rheumatoid arthritis; JIA = juvenile idiopathic arthritis; Pval = gene-level P-value based on fastBAT method; TopSNP = the top associated GWAS SNP; TopSNP_Pval = smallest singleSNP GWAS P-value in the gene region. 
1 Table 2:

2 Genome-wide significant genes outside the HLA region shared by RA and JIA (gene-based

3 P-value $<2 \times 10^{-6}$ )

4 The raw data of genome-wide significant genes of RA are shown in Table S4 and those of JIA

5 are shown in Table S3 and Table S5.

$6 \mathrm{Chr}=$ chromosome; Start-End $=$ Start and end boundaries of the gene region in human genome

7 build UCSC hg19 (NCBI GRCh37); RA = rheumatoid arthritis; JIA = juvenile idiopathic

8 arthritis; Pval = gene-level P-value based on fastBAT method; TopSNP = the top associated

9 GWAS SNP; TopSNP_Pval = smallest single-SNP GWAS P-value in the gene region.

\begin{tabular}{|c|c|c|c|c|c|c|c|}
\hline \multirow[b]{2}{*}{ Gene } & \multirow{2}{*}{\multicolumn{2}{|c|}{ ChrStart-End }} & \multicolumn{3}{|c|}{$\mathbf{R A}$} & \multicolumn{2}{|c|}{ JIA } \\
\hline & & & Pval & TopSNP_Pval & TopSNP & TopSNP_Pval & TopSNP \\
\hline PHTF1 & 1 & $114239823-$ & $7.41 \mathrm{E}-43$ & $1.7 \mathrm{E}-38$ & rs 1217416 & $3 \mathrm{E}-25$ & rs6679677 \\
\hline RSBN1 & 1 & $114304453-$ & $2.08 \mathrm{E}-19$ & $2.8 \mathrm{E}-35$ & rs3811019 & $3 \mathrm{E}-25$ & rs6679677 \\
\hline ANKRD55 & 5 & $55395506-55529186$ & 2.42E-09 & $7.3 \mathrm{E}-24$ & rs 7731626 & $3 \mathrm{E}-11$ & rs 10213692 \\
\hline$I L 2 R A$ & 10 & $6052656-6104333$ & $4.58 \mathrm{E}-07$ & $1.5 \mathrm{E}-10$ & rs 706778 & $8 \mathrm{E}-10$ & rs7909519 \\
\hline SUOX & 12 & $56391042-56399309$ & $6.95 \mathrm{E}-07$ & $3.7 \mathrm{E}-07$ & rs701006 & 4E-09 & rs 1689510 \\
\hline LOC100996324 & 18 & $12739484-12749421$ & $5.76 \mathrm{E}-11$ & $3.4 \mathrm{E}-15$ & rs 2847297 & $1 \mathrm{E}-12$ & rs2847293 \\
\hline PTPN2 & 18 & $12785476-12884334$ & 9.99E-14 & $1.1 \mathrm{E}-15$ & rs 7241016 & $1 \mathrm{E}-12$ & rs 2847293 \\
\hline TYK2 & 19 & $10461203-10491248$ & $4.02 \mathrm{E}-07$ & $2.7 \mathrm{E}-06$ & rs 12459219 & $1 \mathrm{E}-10$ & rs 34536443 \\
\hline
\end{tabular}




\section{Table $\mathbf{3}$ (on next page)}

Enriched pathways shared by RA and JIA after loci in the HLA region being removed (Qvalue<0.05). 
1 Table 3:

2 Enriched pathways shared by RA and JIA after loci in the HLA region being removed (Q3 value $<$ 0.05).

4 Pathway $=$ Abbreviation for each enriched pathway; Database $=$ Database which the gene set of 5 each pathway was extracted from; Size = total number of genes in each pathway; RA =

6 rheumatoid arthritis; JIA = juvenile idiopathic arthritis; Count= the number of RA/JIA-

7 significant genes falling into each pathway; Pval = P-value of each pathway; Qval = Q-value of 8 each pathway based on the trend curve adjusted gene scores.

\begin{tabular}{|c|c|c|c|c|c|c|c|c|}
\hline \multirow[b]{2}{*}{ Pathway } & \multirow[b]{2}{*}{ Database } & \multirow[b]{2}{*}{ Size } & \multicolumn{3}{|l|}{$\mathbf{R A}$} & \multicolumn{3}{|l|}{ JIA } \\
\hline & & & Count & Pval & Qval & Count & Pval & Qval \\
\hline $\begin{array}{l}\text { TYPE I DIABETES } \\
\text { MELLITUS }\end{array}$ & KEGG & 44 & 23 & $1.66 \mathrm{E}-07$ & $1.58 \mathrm{E}-05$ & 41 & $2.12 \mathrm{E}-05$ & 0.001785 \\
\hline IL27 PATHWAY & PID & 26 & 26 & 0.001158 & 0.027447 & 25 & 4.79E-08 & 8.63E-06 \\
\hline NO2IL12 PATHWAY & BIOCARTA & 17 & 15 & 0.002316 & 0.047593 & 16 & $1.87 \mathrm{E}-05$ & 0.001686 \\
\hline
\end{tabular}

